\title{
PENGGUNAAN MEDIA KOMUNIKASI DALAM SOSIALISASI PROGRAM URBAN FARMING DI KOTA SURABAYA
}

\author{
Henny Sri Mulyani R, Herlina Agustin \\ Universitas Padjadjaran Bandung \\ henny.sri.mulyani@unpad.ac.id, heragustin@yahoo.com
}

\begin{abstract}
Communication media is a source of power, a control tool that can be utilized as a substitute for power or other resources, besides the media is a vehicle that plays a role to socialize the events of community life both individually and collectively. To provide food availability independently and sustainably it needs a breakthrough program through the concept of gardening in the yard of the house or the use of empty land for planting productive crops. The purpose of research to find out how the background of media usage, type of media used and the form of presentation of messages used in the socialization of urban farming program in the city of Surabaya. The research method used is descriptive qualitative with data collection interview, observation and literature study. The results showed that the delivery of agricultural messages in urban areas from the Surabaya City Agriculture Office to poor families (Gakin) scattered in 31 sub-districts did not use mass media on the grounds that the gakin community rarely mengengan radio, see television and read the print media so generally the delivery of direct messages done facilitator in this case PPL to poor community society by direct way of technical guidance in the form of group. Media used more to media antarpersona communication. Message delivered on how to do urban farming activities for vegetables with a short harvest period of approximately one month, the use of narrow land in the yard so as to support household-scale food security and add green or green open space.
\end{abstract}

Keywords: socialization, communication media, urban farming, poor families

\section{PENDAHULUAN}

Fungsi media komunikasi pada hakikatnya lebih luas jangkauannya ketimbang media massa yang saat ini dikenal. Media komunikasi adalah sumber kekuatan, alat kontrol yang dapat didayagunakan sebagai pengganti kekuatan atau sumber daya lainnya, selain itu media merupakan wahana yang berperan untuk menyosialisasikan peristiwaperistiwa kehidupan masyarakat baik secara individu maupun secara kolektif.
Peran media dalam masyarakat tersebut berkaitan dengan erat dengan fungsi media pada umumnya yang berada dalam ranah komunikasi massa. Effendy (2001) menyebutkan bahwa setidaknya ada lima fungsi mendasar pada komunikasi massa, yaitu : pengawasan (surveillance), penafsiran (interpretation), pertalian (linkage), penyebaran nilai-nilai (transmission of value) dan hiburan (entertaint). Fungsi komunikasi massa secara umum adalah fungsi informasi, fungsi pendidika dan fungsi mempengaruhi. 
Fungsi utama dalam melakukan komunikasi melalui media komunikasi tersebut dapat digunakan oleh lembaga pemerintahan dalam penelitian ini adalah Dinas Pertanian dan Ketahanan Pangan Kota Surabaya dalam menyebarkan informasi mengenai kegiatan urban farming (pertanian diperkotaan) yang dibutuhkan masyarakat. Untuk menyediakan ketersediaan pangan secara mandiri dan berkelanjutan maka diperlukan adanya terobosan program melalui konsep berkebun dipekarangan rumah atau pemanfaatan lahan kosong untuk ditanami tanaman produktif, intensifikasi lahan, menanam tanaman yang mempunyai nilai ekonomi. Hal ini merupakan sebuah inovasi yang dapat mendukung produksi pangan untuk skala rumah tangga.

Aspek lain yang berkaitan dengan praktek urban farming dalam Widyawaty (2013) adalah optimalisasi pemanfaatan lahan perkotaan tanpa menimbulkan dampak negatif bagi lingkungan hidup perkotaan sehingga memperoleh nilai manfaat seperti memulihkan dan meningkatkan kesehatan lingkungan, meningkatkan kesehatan pangan, memperluas kesempatan ekonomi, perbaikan sosial, efisiensi energi dan meningkatkan ketersediaan dan kualitas pangan.

Berdasarkan pengamatan di indonesia ada dibeberapa kota seperti Surabaya, Malang, Yogyakarta, DKI Jakarta, Tangerang Bandung dan beberapa kota lain telah melaksanakan konsep urban farming yang dikelola oleh komunitas dengan pengawasan dari pemerintah kota. Kondisi perkotaan yang sangat minim pekarangan, bahkan tidak ada halaman rumah maka Rooftop Gardening (berkebun di atap rumah/gedung) bisa menjadi solusi untuk bisa menanam sayuran atau buah-buahan. Rumah akan lebih produktif karena menghasilkan sayur- sayuran dan buah-buahan segar setiap harinya, meningkatkan gizi keluarga, udara segar karena uang belanja sayuran dan buahbuahan sehari- hari sehingga meningkatkan perekonomian keluarga. Bertanam secara vertikultur (budidaya tanaman dengan rak bertingkat) dapat menjadi alternatif. Akan tetapi cara budidaya ini tetap memerlukan ruang yang cukup untuk meletakkan media /rak vertikultur. Jangankan pekarangan untuk menata media vertikultur, untuk jalan saja kadang hanya merupakan gang sempit pada perumahan di perkotaan.

Ada perubahan proporsi urban rural di Jawa, fakta menunjukkan 20 tahun yg lalu, Pulau Jawa ini $70 \%$ pedesaan $30 \%$ kota, sedangkan saat ini $60 \%$ kota dan $40 \%$ pedesaan. Percepatan pertumbuhan yang sangat luar biasa, sehingga konversi dari lahan pertanian ke non pertanian terlalu cepat. Dengan makin tumbuh dan bergesernya rural menjadi urban yang modern, tentu hal ini cukup "menganggu" bagi ketahanan pangan di masa depan.

Kesadaran akan kebutuhan udara yang bersih, kenyamanan dalam lingkungan hidup, makin membuat konsep urban farming ini diterima lebih cepat oleh warga kota. Bahkan dengan lahan yang sempit pun kreatifitas warga kota tidak akan berkurang. 
Kondisi ini didukung pula oleh program dan kebijakan pemerintah kota Surabaya, dengan cepat mengembalikan fungsi jalur hijau pada fungsi yang sebenarnya. Hingga saat ini RTH (Ruang Terbuka Hijau) di Surabaya mencapai $20 \%$. Tentunya pembangunan taman kota, makin difungsikannya kebun bibit, adanya gerakan green and clean dan surabaya berbunga akan makin mendorong pihak swasta dan warga kota berbenah.

Salah satu untuk menyosialisasikan kegiatan pertanian di perkotaan yaitu melalui media komunikasi, karena sudah banyak diakui peran media sesuai dengan fungsinya. Oleh karena itu penelitian ini penting untuk dilakukan untuk mengukur bagaimana peran dan fungsi media dalam program pertanian diperkotaan. Berdasarkan latar belakang penelitian maka perumusan masalahnya adalah bagaimana penggunaan media komunikasi dalam sosialisasi program urban farming (Pertanian diperkotaan) di Kota Surabaya.

Penggunaan media didorong oleh adanya kebutuhan dan tujuan yang ditentukan oleh pengguna. Jay G. Blumber dalam Morissan (2010) mengemukakan sejumlah gagasan mengenai jenis-jenis kegiatan yang dilakukan melalui penggunaan media. Sementara Rosengren dalam Rakhmat (2005) menjelaskan bahwa penggunaan media terdiri dari jumlah waktu yang digunakan, jenis media yang dikonsumsi dan hubungan individu dengan isi media atau media secara keseluruhan. Jenis media massa yang dapat digunakan dalam memasyarakatkan program urban farming dapat berupa media massa cetak seperti surat kabar, majalah dll sementara media elektronik yang dapat digunakan diantaranya melalui radio dan televisi. Bahkan sesungguhnya tidak menutup kemungkinan media online juga dapat digunakan.

Pengertian sosialisasi secara umum dapat diartikan sebagai proses belajar individu untuk mengenal dan menghayati norma-norma serta nilai-nilai sosial sehingga terjadi pembentukan sikap untuk berperilaku sesuai dengan tuntutan atau perilaku masyarakatnya. Dalam KBBI Sosialisasi artinya suatu proses belajar seorang anggota masyarakat untuk mengenal dan menghayati kebudayaan masyarakat di lingkungannya.

Tujuan sosialisasi di antaranya memberi keterampilan dan pengetahuan yang dibutuhkan untuk melangsungkan kehidupan seorang kelak di tengah-tengah masyarakat tempat dia menjadi salah satu anggotanya, Menambah kemampuan berkomunikasi secara efektif dan efisien serta mengembangkankemampuannya untuk membaca, menulis, dan bercerita, membantu pengendalian fungsi-fungsi organic yang dipelajari melalui latihan mawas diri yang tepat dan membiasakan individu dengan nilainilai dan kepercayaan pokok yang ada pada masyarakat.

Latar belakang konsep urban farming didasarkan pada perspektif lingkungan dan nilai ekonomis. Keterbatasan lahan bukan merupakan hambatan untuk mengaktualkan potensi ekonomi yang dimiliki. 
Permasalahan perkotaan akibat urbanisasi dapat dikelompokan dalam beberapa aspek diantaranya aspek fisik, sosial dan ekonomi.

Urgensi pengembangan konsep pertanian perkotaan atau urban farming di negara dunia ketiga termasuk Indonesia cenderung didorong oleh tingginya pertumbuhan penduduk dan urbanisasi sehingga daya dukung perkotaan tidak dapat menopang sebagian kehidupan masyarakat dengan layak seperti tempat tinggal, infrastruktur publik, kerawanan pangan, permasalahan lingkungan seperti sanitasi dan polusi.

Masalah pada aspek sosial di antaranya lahan perumahan untuk setiap keluarga semakin sempit, lahan yang semula untuk aktivitas pertanian dipinggiran kota berubah fungsi menjadi pemukiman, perkantoran, pabrik dan lain-lain, limbah aktivitas masyarakat kota semakin meningkat sehingga menimbulkan polusi, ruang terbuka hijau terbatas, semakin banyak wilayah kumuh, kurang resapan air hujan, dll.

Masalah aspek sosial diantaranya tingkat pengangguran, kesenjangan level pendidikan, kenyamanan lingkungan, keamanan, kesenjangan sosial, kesehatan masyarakat, meningkatnya kejahatan dan kekerasan dan lain-lain. Masalah aspek perekonomian, diantaranya kesenjangan kemmpuan ekonomi, mahalnya biaya hidup, mahalnya biaya pemukiman, mahalnya biaya kesehatan, mahalnya biaya pendidikan dll.

\section{METODE PENELITIAN}

Menurut Cresswell (2010) penelitian kualitatif merupakan metode-metode untuk mengeksplorasi dan memahami makna yang oleh sejumlah individu atau sekelompok orang dianggap berasal dari masalah sosial atau kemanusiaan. Proses penelitian kualitatif ini melibatkan upaya-upaya penting, seperti mengajukan pertanyaan-pertanyaan dan prosedur-prosedur, mengumpulkan data yang spesifik dari para partisipan, menganalisis data secara induktif mulai dari tema-tema yang khusus ke tema-tema umum dan menafsirkan makna data.

Mengacu pada penjelasan Guba dan Lincoln dalam Mulyana (2001) penelitian ini menggunakan paradigma konstruktivisme, relativisme baik realitas lokal maupun spesifik yang dikonstruksikan bersama-sama (constructed) menjadi aspek ontologi. Aspek epistemologi dalam paradigma konstruktivisme bersifat transaksional atau subjektivis berpa penemuan yang diciptakan bersama-sama (cocreated). Sementara aspek metodologi bersift hermeneutis atau dialektis.

Metode penelitian yang digunakan adalah metode deskriptif kualitatif. Data dalam metode kualitatif dianalisi secara induktif. Menurut Moleong (2001) pencarian data bukan dimaksudkan untuk membuktikan hipotesis yang telah dirumuskan sebelum penelitian diadakan. Analisis ini lebih merupakan abstraksi berdasarkan bagian-bagian yang telah dikumpulkan, kemudian dikelompokkan. 
Sumber data yang menjadi subjek dalam penelitian ini didasari pertimbangan bahwa individu dianggap khas sebagai subjek penelitian atau key informan, di antaranya adalah :

1. Masyarakat pelaku urban farming

2. Birokrat yang berkontribusi pada pewujudan kegiatan urban farming, yaitu fasilitator kelurahan (faskel)

3. Pelaksana di Dinas pertanian Kota Surabaya.

\section{HASILDAN PEMBAHASAN}

Luas wilayah seluruh Kota Surabay $32.637,75 \mathrm{Ha}$ artinya luasan yang haru diperuntukkan untuk ruang terbuka hija sebesar 6.527,55 Ha. Berdasarkan Rencana Tat Ruang Wilayah (RTRW) kota Surabaya 201: ko ndisi eksisting ruang terbuka hijau selua 171,68 Ha. Luasan tersebut terdiri dari 103,2 Ha taman kota, 30,64 Ha lapangan olahraga, dan 37,75 Ha makam. Perlu upaya keras untuk mewujudkan 6.247,47 Ha lahan sebagai ruang terbuka hijau.

Menurut Peraturan Daerah Kota Surabaya nomor 07 tahun 2002, tentang pengelolaan ruang terbuka hijau disebutkan bahwa ruang terbuka hijau tak hanya berupa hutan kota, melainkan kawasan hijau yang berfungsi sebagai pertamanan, rekreasi, permakaman, pertanian, jalur hijau, dan pekarangan. Dalam ruang terbuka hijau diwajibkan adanya kegiatan penghijauan yaitu tentunya dengan budidaya tanaman sehingga terjadi perlindungan terhadap kondisi lahan.
Peraturan daerah itu menyebutkan dengan jelas bahwa pengelolaan ruang terbuka hijau menjadi tanggungjawab tak hanya pemerintah, bahkan sektor swasta, dan warga yang bertempat tinggal di Kota Surabaya.

Pemerintah Kota Surabaya lewat Musyawarah Perencanaan Pembangunan Kota Surabaya tahun 2009 mengutarakan strategi penambahan ruang terbuka hijau antara lain sebagai berikut :

\section{Tabel 1. Rencana Ruang Terbuka Hijau}

$\begin{array}{ll}\text { Jenis ruang terbuka hijau } & \begin{array}{l}\text { Luas } \\ \text { yang direncanakan (Ha) }\end{array} \\ \text { Prasarana lingkungan } & 92,5 \\ \text { Boezem } & 47,31 \\ \text { Lapangan/taman } & 38,56 \\ \text { Makam } & 69,86 \\ \text { Pedestrian } & 1,3 \\ \text { Urban Farming } & 26,35 \\ \text { Jumlah } & 275,88\end{array}$

Berdasarkan rencana tersebut, artinya pemerintah kota berkomitmen merealisasi 275,88 Ha lahan di Kota Surabaya yang difungsikan sebagai ruang terbuka hijau. Khususnya untuk program urban farming seluas 26,35 Ha.

Kota Surabaya mempunyai kebijakan keluarga miskin (GAKIN) dijadikan sasaran implementasi urban farming yang dimotori oleh beberapa elemen pemerintahan. Dinas Pertanian dan Perikanan. Keluarga miskin menjadi prioritas sasaran karena jumlah angka kemiskinan menurut data tahun 2007 mencapai 126.000 jiwa, sekalipun disinyalir terjadi penurunan pada tahun lalu. 
Perlu dikritisi bahwa program yang bersifat hibah ini masih belum dipikirkan secara serius keberlanjutannya, agar tidak memunculkan ketergantungan melainkan sebaliknya, menghidupi kemandirian.

Sejak ditetapkan sebagai salah satu bentuk pengentasan kemiskinan tahun 2010, urban farming di kota Surabaya telah mengalami beberapa perubahan model sosialisasi dan kebijakan. Pada tahun 2010, ada 37.199 kepala keluarga yang menjadi target urban farming. Data ini diambil dari Badan Perencanan dan Pembangunan Daerah mengenai kategori keluarga miskin, kemudian oleh Dinas Pertanian kota Surabaya, setiap KK yang termasuk dalam data tersebut diberi 1 paket bantuan untuk pelaksanaan urban farming. Paket tersebut berisi peralatan urban farming berupa hand sprayer, gembor plastic, kantong polybag, pot plastic, media tanam, pupuk NPK, pupuk urea, pupuk ZA, pupuk organik cair, pupuk kandang, bamboo air, bayam, sawi, kangkung, cabe lokal, terong, bayam merah, kedelai, kacang panjang, dan tauge.

Setelah setahun, Dinas pertanian Kota Surabaya kemudian melakukan evaluasi dan akhirnya menyatakan banyak hal yang tidak berjalan seperti yang diharapkan. Pada tahun 2011 kemudian ditetapkan 500 kelompok urban farming dengan jumlah kepala keluarga sebanyak 6.000 kepala keluarga, dengan dibantu 31 petugas lapangan yang berada di tiap kecamatan.
Tahun berikutnya, 2012, Dinas Pertanian Kota Surabaya masih menyusun target 6.000 kepala keluarga miskin yang dijadikan sasaran urban farming. Sebagian diantaranya merupakan peserta urban farming baru.

Pertengahan 2013, target peserta urban farming kota Surabaya menurun lagi menjadi 3.000 kepala keluarga. Hal ini diakibatkan evaluasi sebelumnya yang menganggap 6.000 kepala keluarga masih terlalu berat bagi 31 petugas lapangan di tiap kecamatan. Selain itu pada tahun ini sudah diterapkan sistem kompetisi. Setiap kelompok urban farming yang dianggap berhasil mendapat bantuan lebih dari Dinas Pertanian, berupa peralatan perkebunan tambahan dan tanaman.

Tahun 2014 dinilai bahwa angka 3.000 merupakan angka yang cukup memadai untuk dikerjakan oleh 31 petugas lapangan yang dibantu oleh fasilitator kelurahan dalam program urban farming. Gambaran lengkap mengenai sarana yang diberikan Dinas Pertanian Kota Surabaya untuk kegiatan urban farming dapat dilihat pada tabel 2 berikut ini :

Tabel 2. Pelaksanaan Urban Farming

\begin{tabular}{|c|c|c|}
\hline 2010 & Jumlah KK & \multicolumn{1}{|c|}{ Paket Urban Farming } \\
\hline 2011 & 6000 & $\begin{array}{l}\text { Hand sprayer, polybag, } \\
\text { pot plastik, media } \\
\text { tanam, pupuk (NPK, } \\
\text { urea, ZA, organik cair, } \\
\text { kandang), bibit (bambu } \\
\text { air, bayam, kangkung, } \\
\text { cabe, terong, kedelai, } \\
\text { kacang panjang }\end{array}$ \\
\hline 2012 & 6000 & Tahun \\
\cline { 1 - 2 } 2014 & 3000 & \multicolumn{2}{|c}{} \\
\hline
\end{tabular}

Sumber : Hasil Penelitian 
Latar Belakang Penggunaan Media dalam Sosialisasi Program Urban Farming

Penggunaan media dalam sosialisasi kegiatan urban farming di kota Surabaya bersifat antarpersona tidak memanfaatkan media komunikasi massa. Hal ini lebih dilatarbelakangi adanya asumsi di Dinas Pertanian yaitu masyarakat keluarga miskin (gakin) cenderung pasif dalam mencari informasi lewat media. Jadi anggapannya cukup dengan melakukan pertemuan. Pertemuan yang dilakukan antara : Dinas Pertanian dengan petugas PPL, fasilitator kelurahan, masyarakat keluarga miskin.

Seluruh kegiatan sosialisasi, bimbingan teknik mengenai urban farming di Kota Surabaya bersifat komunikasi antarpersona atau komunikasi kelompok. Sosialisasi tidak memanfaatkan peran dan fungsi komunikasi massa dengan menggunakan media massa baik cetak maupun elektronik. Padahal fungsi media komunikasi pada hakekatnya lebih luas jangkauannya ketimbang media massa yang saat ini dikenal.

Media komunikasi adalah sumber kekuatan, alat kontrol yang dapat didayagunakan sebagai pengganti kekuatan atau sumber daya lainnya, selain itu media merupakan wahana yang berperan untuk mensosialisasikan peristiwa-peristiwa kehidupan masyarakat baik secara individu maupun secara kolektif. Effendy (2001 : 29) menyebutkan bahwa setidaknya ada lima fungsi mendasar pada komunikasi massa, yaitu : pengawasan (surveillance), penafsiran (interpretation), pertalian (linkage), penyebaran nilai-nilai (transmission of value) dan hiburan (entertaint). Fungsi komunikasi massa secara umum adalah fungsi informasi, fungsi pendidika dan fungsi mempengaruhi.

Fungsi utama dalam melakukan komunikasi melalui media komunikasi tersebut dapat digunakan oleh lembaga pemerintahan dalam penelitian ini adalah Dinas Pertanian dan Ketahanan Pangan Kota Surabaya dalam menyebarkan informasi mengenai kegiatan urban farming (pertanian diperkotaan) yang dibutuhkan masyarakat.

Sosialisasi kegiatan program urban farming cenderung bersifat penyuluhan dengan teknik penyampaian pesan dalam bentuk ceramah dan diskusi kelompok. Ceramah dilakukan ketika Dinas Pertanian mengundang kepala keluarga dari keluarga miskin untuk diberikan pencerahan mengenai kegiatan urban farming dengan segala manfaatnya. Dinas pertanian dibantu oleh para petuga PPL yang akan membimbing dan menjadi fasilitator.

Bentuk diskusi kelompok dilakukan antara petugas PPL dengan fasilitator kelurahan dan masyarakat yang mendapat bantuan sarana untuk melakukan kegiatan urban farming. Kegiatan ini tidak terlalu peridik tapi hanya beberapa kali dalam satu kali program. Selanjutnya petugas PPL berkoordinasi dengan fasilitator kelurahan sesuai dengan wilayah kerjanya. Biasanya seorang petugas PPL dapat membina 3 kelurahan yang siap dengan diskusi kelompok di masing-masing kelurahan. 
Media penyampaian informasi dari petugas PPL dengan masyarakat hanya dalam bentuk pemaparan dan contoh melakukan kegiatan urban farming.

\section{Media Sosialisasi Program Urban Farming}

Penyebaran pesan informasi mengenai kegiatan urban farming di kota Surabaya selama ini dilakukan tidak memanfaatkan media komunikasi baik media cetak maupun media elektronik tetapi kegiatan dilakukan dengan komunikasi antarpersona dan komunikasi kelompok. Media penyampaian informasi biasanya hanya dalam bentuk contohcontoh kegiatan urban farming bisa dalam bentuk slide, foto yang disajikan saat melakukan bimbingan teknis dari PPL pada fasilitator kelurahan dan masyarakat keluarga miskin (gakin). Media komunikasi massa pada sosialisasi program Urban Farming di Kota Surabaya sama sekali tidak digunakan. Mereka hanya mengandalkan konteks komunikasi antar persona. Sesungguhnya fungsi komunikasi massa menurut Efendi (2001 :29) yaitu pengawasan, interpretasi, hubungan, sosialisasi dan hiburan tidak dimanfaatkan.

Bentuk Penyajian Pesan Yang Digunakan Dalam Sosialisasi Program Urban Farming Penyampaian pesan berupa bimbingan teknis yang dilakukan petugas PPL dari dinas Pertanian Kota Surabaya kepada fasilitator kelurahan dan masyarakat keluarga miskin yang mendapat bantuan sarana untuk kegiatan urban farming dalam bentuk ceramah dan diskusi kelompok. Pesan yang disampaikan umumnya dalam konteks komunikasi antarpersona dan komunikasi kelompok antara petugas lapangan dengan fasilitator kelurahan dan masyarakat keluarga miskin. Pesan disajikan cenderung dalam bentuk pesan verbal atau non verbal.

Alat bantu pesan berupa contoh-contoh bentuk kegiatan urban farming berupa foto, slide tentang teknik pelaksanaan kegiatan berkebun dengan pemanfaatan lahan tidur, halaman rumah, pinggiran gang, dinding gang dan lain sebagainya

Urban farming atau pertanian diperkotaan cenderung pada kegiatan menanan sayuran karena umumnya keluarga miskin tidak mempunyai lahan pekarangan yang luas yang dapat diunakan untuk beternak lele. Pada tahun 2014 mulai kegiatan urban farming menyentuh bidang peternakan dengan diberinya bibit lele. Tapi hanya untuk daerah tertentu misal daerah Krembangan pertimbangannya karena di daerah tersebut terdapat Bozem yang sangat luas yang terhampar di tepi lingkungan pemukinam keluarga miskin (Gakin) yang dapat dimanfaatkan untuk beternak lele.

"Mereka mendapat bantuan teknis dari pendamping ahli di lapangan, supaya tidak kaget. Sebagian besar dari mereka masih awam dengan kegiatan perikanan atau pertanian”.

Dinas Pertanian Kota Surabaya tampaknya tak patah arang dengan pelaksanaan proyek urban farming di kota ini. Meski sempat beberapa kali mengalami kegagalan, terutama urban farming di kawasan perkotaan, namun dinas ini tetap mengalokasikan anggaran untuk pelaksanaan program urban farming 2013. 
Pihak dinas kembali mengalokasikan anggaran untuk pelaksanaan urban farming di tahun 2013 sebesar Rp 1 miliar.

\section{SIMPULAN}

Media komunikasi selama ini tidak digunakan sebagai penyampaian pesan urban farming untuk keluarga miskin atau gakin lebih dilatarbelakangi bahwa pada umumnya masyarakat keluarga miskin pasip dalam pencarian informasi melalui media massa dan keterbatasan kemampuan ekonomi jadi penyebaran informasi dilakukan secara antarpersona antara Dinas Pertanian Kota Surabaya, petugas PPL, fasilitator kelurahan dan masyarakat keluarga miskin dalam bentuk bimbigan teknis.

Sebagai saran perlu dilakukan evaluasi oleh Dinas Pertanian Kota Surabaya mengenai asumsi masyarakat keluarga miskin yang dianggap pasip dalam pencarian informasi melalui media komunikasi sehingga selama ini bentuk sosialisasi program urban farming dilakukan secara antarpersona. Diharapkan untuk tahun-tahun selanjutnya penggunaan media komunikasi dapat dijadikan media penyampai informasi urban farming.

\section{REFERENSI}

Bungin, Burhan. (2008). Sosiologi Komunikasi. Jakarta : Kencana Prenada Media Group.

Creswell, John W. (2010). Research Design Pendekatan Kualitatif, Kuantitatif dan Mixed. Yogyakarta : Pustaka Pelajar.
Effendy, Onong Uchjana. (2001). Ilmu, Teori dan Filsafat Komunikasi. Bandung : PT.Citra Aditya Bakti.

Littlejohn, Stephen W \& Foss, Karen A. (2009). Encyclopedia of Communication Theory. California: SAGE Publications, Inc (2009). Teori

komunikasi. Penerjemah Mohammad Yusuf Hamdan. Jakarta : Salemba Humanika.

Moleong. (2001). Metodologi Penelitian Kualitatif. Bandung: Remaja Rosdakarya.

Morrisan. (2010). Teori Komunikasi Massa. Bogor: Ghalia Indonesia

Mulyana, Deddy. (2001). Metodologi Penelitian Kualitatif. Bandung : Remaja Rosdakarya.

Poloma, Margaret. (1987). Sosiologi Kontemporer. Jakarta: Rajawali

Prasetio, Bambang. (2013). Budi Daya Sayuran Organik di Pot. Yogyakarta: Andi Offset.

Rakhmat, Jalaludin (2005). Psikologi Komunikasi. Bandung. Remaja Rosdakarya.

Severin, Werner J \& Tankard, James W. (2005). Teori komunikasi. Alihbahasa Sugeng Hariyanto. Jakarta : Prenada Media.

Silalahi, Ulber. (2010). Metode Penelitian Sosial. Bandung : PT.Refika Aditama.

Soekanto, Soerjono. (1990). Sosiologi Suatu pengantar. Jakarta: Raja Grafindo Persada.

Tan, Alexis. (1981). Mass Communication Theories And Research. Ohio Columbus: Grid Publishing Inc.

Widyawati, Nugraheni. (2013).Urban Farming Gaya Bertani Spesifik Kota. Yogyakarta : Lily Publisher.

Wirawan I.B. (2012). Teori-Teori Sosial Dalam Tiga Paradigma. Jakarta : Kencana. 